\title{
资源环境承载能力预警城市化地区专项评价 以京津冀地区为例
}

\author{
周道静 ${ }^{1,2}$, 王传胜 ${ }^{1,2}$ \\ (1. 中国科学院区域可持续发展分析与模拟重点实验室,北京 100101 ; \\ 2. 中国科学院地理科学与资源研究所, 北京 100101)
}

\begin{abstract}
摘 要: 资源环境承载能力预警评价中,除基础评价外, 还需针对城市化地区存在的特殊问题开展专项评价。但现 有相关研究大多较为复杂、难以操作,且较少考虑目前中国城市化地区之间存在的发展水平差异, 难以满足实际应 用需求。本文根据近年来中国城市化地区资源环境凸显的主要问题, 从城市人居环境人手, 选取城市黑臭水体和 PM2.5 超标天数 2 个要素设计城市水气环境黑灰指数, 作为城市化地区专项评价的主要指标; 同时考虑到优化开 发区域和重点开发区域的主体功能导向差异, 以京津冀城市化地区为例开展试评价分析, 结果显示: 京津冀城市化 地区的 104 个区县中, 47 个区县为重警, 46 个中警, 仅 11 个为轻警,整体形势不容乐观。其中, 重警区县主要集中 在京广高铁沿线,与地区主要交通线路分布及钢铁工业聚集格局一致; 轻警区县主要分布在北部的张承地区及东 部沿海, 工业相对较少, 且地理位置有利于污染物迅速扩散。城市化地区专项评价作为基础评价的补充, 能更清晰 地反映现阶段影响城市人居环境的主要制约因子以及不同发展水平地区间的差异,评价结果可为城市化地区开展 国土空间规划、城镇发展战略研究和产业结构调整等提供科学依据。
\end{abstract}

关 键 词: 资源环境承载能力; 预警评价; 城市化地区; 城市水气环境黑灰指数; 评价阈值; 京津冀地区

\section{1 引言}

资源环境承载能力是指自然基础对人类生产 生活活动的支持能力, 其内涵涉及自然基础条件和 社会经济发展 2 个维度。在相同的自然基础条件 下, 不同的开发功能和利用效率, 其可承载的经济、 人口规模不同(陆大道等, 2012; 㚞杰, 2014; 焚杰 等, 2015)。资源环境承载能力预警是通过对资源 环境超载状况的评价, 对区域可持续发展状态进行 诊断和预判, 为制定差异化、可操作的限制性措施 奠定基础。因此, 在全国资源环境承载能力监测预 警评价的整体框架中,不仅需要针对普遍存在的自 然资源环境要素(如水土资源、生态、环境等)进行全
域范围的基础评价, 还需针对不同发展方式与发展 水平地区出现的特殊问题, 开展相应的专项评价 (Fan et al, 2017)。城市化地区是以提供工业品和服 务产品为主体功能的地区, 是《全国主体功能区规 划》中按开发内容划分的 3 类主体功能区之一。城 市化地区作为人口和经济的主要集聚地区, 是人类 活动最活跃的区域,也是资源环境承载人类活动能 力最强的区域, 又是资源环境与人类活动矛盾凸显 的区域。因此,对城市化地区开展资源环境承载能 力预警评价时,除基础性的水土资源和生态环境评 价外, 针对其人口集中、人类活动强等典型特征, 从 城市人居环境的角度人手, 开展专项评价分析城市 人居环境的突出问题,对清晰认识整个评价区域的

收稿日期: 2017-02; 修订日期: 2017-03。

基金项目: 国家自然科学基金项目(41630644); 中国科学院科技服务网络计划(STS 计划)项目(KFJ-STS-ZDTP-021) [Foundation: National Natural Science Foundation of China, No. 41630644; Science and Technology Service Network Initiative of the Chinese Academy of Sciences, No. KFJ-STS-ZDTP-021]。

作者简介: 周道静(1986-),女, 江苏盐城人,博士后, 主要从事区域生态承载力研究, E-mail: zhoudj@igsnrr.ac.cn。

通讯作者:王传胜(1965-), 男, 山东青岛人, 副研究员, 主要从事区域发展研究,E-mail: wangcs@igsnrr.ac.cn。

引用格式: 周道静, 王传胜. 2017. 资源环境承载能力预警城市化地区专项评价: 以京津冀地区为例 [J]. 地理科学进展, 36(3): 359-366. [Zhou D J, Wang C S. 2017. Specific evaluation of resource and environmental carrying capacity of urbanized areas for early-warning: A case study of the Beijing-Tianjin-Hebei region[J]. Progress in Geography, 36(3): 359-366.]. DOI: 10.18306/dlkxjz.2017.03.012 
资源环境承载状态尤为重要。

自19世纪末 “承载力”这一概念被正式提出以 来, 其内涵已从最初的单纯研究特定区域可维持某 一物种个体的最大数量, 扩展到在区域可持续发展 目标下对自然基础与人类活动之间动态交互过程 的综合研究(刘晓丽等, 2008; 禁杰等, 2015)。城市 作为人类活动与自然环境交互最为强烈的地区, 已 经成为承载力理论与实践研究的热点。早期, 城市 化地区的承载力研究主要是基于区域内的水土资 源、粮食产量、环境质量等因素,推算区域目前或未 来可以容纳的最大人口数(Meier, 1978; Huang et al, 1990)。21世纪后, 随着相关理论方法日趋完善, 这一领域的研究也有了新的发展, 主要表现为:一 是研究和分析的视角更加全面, 除传统的自然要素 外, 还增加了对城市服务、公共感知、制度建设等社 会经济要素的考虑(Oh et al, 2005; Liu et al, 2011; Wei et al, 2015; Zheng et al, 2015); 二是评价角度更 加细化, 除对区域整体资源环境承载状况的综合分 析外, 还针对不同类型的资源环境要素及其与人类 活动交互过程的特征差异, 发展了一系列更加精细 化的城市化地区单要素(如城市环境、城市水资源 等)承载力研究的理论与方法(徐琳瑜等, 2005; 夏军 等, 2006; 杨亮等, 2010; Li, 2012; Tehrani et al, 2013; Widodo et al, 2015); 三是研究范围进一步扩 展, 研究区域从早期的单个城市扩展到城市群等更 大范围的区域(吕斌等, 2008; Fang et al, 2010; Liu, 2012)。这些研究不仅进一步改进、拓展了城市资 源环境承载力理论方法体系, 也为实际预警评价工 作提供了有益的理论参考。但是, 以往研究普遍存 在数据获取难度大、方法复杂等问题, 因此难以广 泛应用到实际工作中, 无法满足国家开展系列改革 工作的迫切需求。同时, 目前针对多个城市的研究 主要以同一自然地理单元内部的城市群为主, 城市 个体间的自然条件和社会发展状况具有一定的相 似性, 而对更大尺度内(如全国范围) 具有显著差异 的城市化地区则较少涉及。因此, 发现并提取城市 化地区资源环境存在的特殊问题和突出矛盾, 考虑 不同发展方向及水平城市化地区间的差异, 在此基 础之上构建有效易行的城市化地区专项评价方法, 具有重要意义。

改革开放以来, 中国城市化进程逐步加快, 越 来越多的人口和产业向城市集聚, 城市已成为中国 发展的核心力量(周一星等, 1999; 胡鞍钢, 2003; 许 学强等, 2009; Bai et al, 2014)。近 40 年间, 中国城
镇总人口从 1978 年的 1.7 亿增至 2015 年的 7.7 亿, 100 万人以上城市数量也由 29 个升至 142 个, 城市 数量不断增加, 城市规模持续扩张(樊杰, 2016)。然 而,城市化的快速推进也带来了巨大的资源环境压 力, 与农产品主产区和重点生态功能区相比, 现阶 段中国城市化地区的大气和水环境问题尤为突出, 成为制约城市可持续发展的主要因素(仇保兴, 2007; Chan et al, 2008; 李宇军, 2014)。在大气环境 方面, 2010 年以来, 灰需天气在中国东部地区蔓 延。国家气象局基于能见度的观测显示, 2013 年全 国平均䨪日数为 35.9 天, 为 1961 年以来最多。其 中, 中东部地区雾霧天气多发, 华北中南部至江南 北部的大部分地区雾皬日数范围为 $50 \sim 100$ 天, 部分 地区甚至超过 100 天。根据环保部城市空气质量监 测报告, 2013-2015 年城市大气污染物中 PM2.5 达 标比例最低, 是现阶段影响中国城市大气环境质量 的首要污染物。在水环境方面, 全球变化加剧了中 国水资源安全危机, 水质性缺水成为城市水资源短 缺的主要原因之一。2015 年国务院颁布《水污染防 治行动计划》, 提出了到 2020 年地级及以上城市建 成区黑臭水体控制在 $10 \%$ 以内、2030年总体得到消 除的控制性目标。住建部2016年 2 月公布的城市 黑臭水体调查结果显示, 全国 7 成以上城市存在黑 臭水体,其中 $60 \%$ 分布在东南沿海等经济相对发达 地区。可见, PM2.5 和黑臭水体整治已经成为地方 各级政府改善城市人居环境工作的重要任务。

综上,本文在全国资源环境承载能力监测预警 评价的整体框架下, 选取人居环境劣化作为城市化 地区有别于其他功能区的典型问题, 针对目前中国 城市化地区突显的人居环境劣化因子, 以县级行政 区为评价单元, 研究可在全国范围内适用、可行性较 强的城市化地区专项评价指标及方法, 为全面反映 评价区域整体资源环境承载能力预警状态, 深人分 析现阶段城市化地区资源环境超载成因提供依据。

\section{2 研究区域与评价方法}

\section{1 研究区域}

本文中的城市化地区采用《全国主体功能区规 划》中的定义, 即以提供工业品和服务产品为主体 功能的地区,包括优化开发区域和重点开发区域。 选取的试评价地区一一京津冀城市化地区共有 104 个区县, 占地区全部区县数量的 $51.5 \%$, 具体包括, 北京市的城六区及昌平、顺义、通州、大兴、房山等 
区, 天津市的市内六区、环城四区、远郊两区及滨海 新区,河北省的唐山、秦皇岛、廊坊、沧州、保定、石 家庄、衡水、邯単等市辖区县。104个区县中, 54 个 为优化开发区域, 50 个为重点开发区域。

\section{2 评价准则}

城市是具有开放性、创新性和边界可扩性的地 域空间体, 就单个城市而言, 能够承载多少人口, 负 荷多大的经济体量, 是个很难回答的问题, 但技术 的进步为解决许多在以前看来不可调和的人地矛 盾提供了可能。根据上文所述, 城市化地区专项评 价针对的是功能区资源环境的特殊问题, 且这些特 殊问题与功能区对资源环境要素的开发方式及利 用效率紧密相关, 是城市化地区资源环境承载能力 预警评价的重要组成。据此, 对城市化地区专项评 价设立以下 2 个准则:

一是针对发展阶段, 突出主要问题。由于每个 城市在不同的经济社会发展阶段都会面临相应的 资源环境症结, 因此, 对城市化地区的资源环境承 载能力的认识和预警评价, 必须以现阶段凸显的典 型问题为出发点,进行针对性的评价。

二是根据城市功能, 分类预警评价。城市化地 区的主体功能定位不同、城市规划赋予其的功能不 同, 对资源环境承载能力预警的要求也不一样。优 化开发的城市化地区比重点开发的地区对人居环 境的要求更高一些, 人口集中的城市主城区则比其 他区县的要求更严格一些, 而旅游城市、商贸城市 比工业城市的要求更为严格, 这些差别需要在指标 的阈值划分中分类对待。

此外, 还要考虑指标的可比性、动态性、数据可 获性和方法可行性等准则。

\section{3 指标选择与数据来源}

根据城市化地区专项评价任务和评价准则, 本 文采用城市水气环境黑灰指数作为城市化地区专 项评价指标, 通过对现阶段城市人居环境的主要劣 化因子一一黑臭水体和 PM 2.5 的评价分析, 测度城 市水体黑臭程度与大气灰皬程度, 可综合得出城市 水气环境的劣化程度。其中, 黑臭水体通过城市黑 臭水体分布密度和重度黑臭占比 2 项综合反映, PM2.5 通过超标天数反映。

根据住建部《城市黑臭水体整治工作指南(建 城[2015]130 号)》定义, 城市黑臭水体是指城市建成 区内呈现令人不悦的颜色和(或)散发令人不适气味 的水体。这一指标既能直观反映城市水体的劣化 情况, 又能间接体现城市人居环境的宜居程度。近
2 年,住建部在东部重要城市逐步建立黑臭水体监 测网络, 目前已完成全国 295 个地级及以上城市建 成区黑臭水体的排查工作,并建立监管平台对城市 黑臭水体情况定期进行监测, 本文数据即来源于住 建部城市监测站点的年度数据。PM2.5 在基础评 价中采用的是年均浓度指标, 也是目前 PM2.5 监测 预警的常规指标。但对于城市化地区而言,除了年 均浓度外, 对超标天数特别是中度及以上超标天数 的感知, 可能更能引起城市居民的关注。因此, 本 文采用超标天数作为反映城市化地区空气质量的 主要指标, 该数据可通过环保部城市监测站点的日 均浓度值数据得出。此外, 上述 2 个要素评价均需 考虑城市建成区的大小 (源于住建部城市建成区的 数据)。以上所有数据均采用 2015 年度的监测及统 计数据。

\section{4 单项指标评价方法}

(1) 城市黑臭水体

城市黑臭水体多见于东部河网地区, 主要是由 于水体负荷的污染物量远远超出其自净能力, 水中 溶解氧不足, 有机质腐败造成(方宇尧等, 1993; 于 玉涁等, 2010)。根据住建部 2015 年 8 月发布的《城 市黑臭水体整治工作指南》,城市黑臭水体的监测 指标包括透明度、溶解氧、氧化还原电位和氨氮等, 监测结果划分为轻度黑臭和重度黑臭 2 种(表 1$) 。$

城市黑臭水情况的评价可基于以下 2 个维度: 一是黑臭水体在评价单元中的分布密度, 主要反映 黑臭水体对区域整体人居环境的影响程度;二是重 度黑臭水体占评价单元内全部黑臭水体的比例, 主 要反映区域水体污染的严重程度。一般在平原河 网地区, 城市河道较多, 且因人工疏浚、引水等工 程, 河道多成网络化, 在评价时上述 2 个维度均需考 虑; 而对于河道较少的地区,采用重度黑臭水体占 比即可。在城市化地区的类型方面,按照优化开发 和重点开发的功能导向分为两类; 在城市功能方 面, 将旅游城市和优化开发区域等同考虑, 将工矿

\section{表 1 城市黑臭水体污染程度分级标准}

Tab.1 Classification standard of pollution degree of urban black-odor water bodies

\begin{tabular}{lcc}
\hline \multicolumn{1}{c}{ 特征指标 } & 轻度黑臭 & 重度黑臭 \\
\hline 透明度 $/ \mathrm{cm}$ & $25 \sim 10^{*}$ & $<10^{*}$ \\
溶解氧 $/(\mathrm{mg} / \mathrm{L})$ & $0.2 \sim 2.0$ & $<0.2$ \\
氧化还原电位 $/ \mathrm{mV}$ & $-200 \sim 50$ & $<-200$ \\
氨氮 $/(\mathrm{mg} / \mathrm{L})$ & $8.0 \sim 15$ & $>15$ \\
\hline
\end{tabular}

注: *水深不足 $25 \mathrm{~cm}$ 时, 按实际水深 $40 \%$ 取值。 
城市及其他功能类型与重点开发区域等同考虑。 表 2 是 2 类城市化地区黑臭水体的评价阈值,其中 分级阈值主要根据试评价地区监测数据的分布特 征、辅之以经验判断设定。综合 2 个维度评价得到 最终的城市黑臭水体评价结果, 方法详见表 3 。

(2) PM2.5 超标天数

PM2.5 对人体健康的影响, 不仅取决于浓度, 还与人群暴露程度有关。人口密度大的地区风险 大,不同人群因体质和暴露时间的差异, 面临的健 康风险也不同(World Health Organization, 2006; 傅 崇辉等, 2014; 谢元博等, 2014)。按照中国《环境空 气质量标准》(GB3095-2012), 日均浓度 $75 \mu \mathrm{g} / \mathrm{m}^{3}$ 、年 均浓度 $35 \mu \mathrm{g} / \mathrm{m}^{3}$ 为现阶段中国执行的二级浓度限值 标准, 文中的 PM2.5 超标天数即根据该标准统计得 到。PM2.5 超标天数评价阈值则通过对人群健康 影响的风险程度来评判, 超标天数多, 意味着人群 暴露于 PM2.5 中的时间和机会可能性越大, 人群的 健康风险也就越高; 反之, 风险则越低。表 4 为评价

表 2 城市黑臭水体评价國值(适用于平原河网地区)

Tab.2 Classification standard of density and proportion of urban black-odor water bodies by functional zones (applicable to river network of plain area)

\begin{tabular}{|c|c|c|c|c|c|c|}
\hline \multirow{2}{*}{ 功能区 } & \multicolumn{3}{|c|}{ 黑臭水体分布密度 $/\left(\mathrm{m} / \mathrm{km}^{2}\right)$} & \multicolumn{3}{|c|}{ 重度黑臭占比 $/ \%$} \\
\hline & 低度 & 中度 & 高度 & 低度 & 中度 & 高度 \\
\hline $\begin{array}{l}\text { 优化开发区域 } \\
\text { (旅游城市) }\end{array}$ & $<100$ & $100 \sim 500$ & $\geqslant 500$ & $<25$ & $25 \sim 50$ & $\geqslant 50$ \\
\hline $\begin{array}{l}\text { 重点开发区域 } \\
\text { (其他城市) }\end{array}$ & $<300$ & $300 \sim 800$ & $\geqslant 800$ & $<33$ & $33 \sim 66$ & $\geqslant 66$ \\
\hline
\end{tabular}

表 3 城市黑臭水体评价结果分级表

Tab.3 Classification of urban black-odor water bodies based on their density and proportion

\begin{tabular}{cccc}
\hline 分布密度 & 低度 & 中度 & 高度 \\
\hline 低度 & 较轻 & 一般 & 一般 \\
中度 & 较轻 & 一般 & 严重 \\
高度 & 一般 & 严重 & 严重 \\
\hline
\end{tabular}

表4 PM2.5 超标天数评价阈值(对人群健康的风险程度)

Tab.4 Classification of PM2.5 pollution days in urbanized areas (level of risk for human health)

\begin{tabular}{|c|c|c|c|c|}
\hline 功能区 & 低或无风险 & 中风险 & 高风险 & 极高风险 \\
\hline 优化开发区域(旅游城市) & $<60$ & $60 \sim 120$ & $120 \sim 210$ & $\geqslant 210$ \\
\hline 其中: 核心城市主城区* & $<30$ & $30 \sim 90$ & $90 \sim 180$ & $\geqslant 180$ \\
\hline 重点开发区域(其他城市) & $<120$ & $120 \sim 180$ & $180 \sim 240$ & $\geqslant 240$ \\
\hline 其中: 核心城市主城区 & $<60$ & $60 \sim 120$ & $120 \sim 180$ & $\geqslant 210$ \\
\hline
\end{tabular}

注: *核心城市主要指直辖市、省会或城市人口规模超过 500 万人 的特大及超大城市; 主城区是指城市人口集聚分布的中心城区, 如 北京的城六区。
阈值的具体划分。表中不同级别的阈值是根据试 评价地区目前的发展阶段和监测数据的分布特征 确定, 阈值除按照城市化地区的功能类型设置不同 标准外, 还考虑了人口暴露数量的差异, 即对于人 口规模超过 500 万的特大及超大城市, 针对其主城 区由于人口相对集中导致的人群 PM 2.5 高暴露特 征, 设置更为严格的标准; 重点开发区域作为发展潜 力较大且需要重点发展的城市化地区, 考虑到确保 其适当增长速度的需求,采取较为宽松阈值标准。

\section{5 集成评价方法}

集成黑臭水体及 PM 2.5 超标天数 2 项指标的评 价结果, 得到城市化地区的专项评价结果, 具体方 法见图 1 。由于目前黑臭水体调查数据并未实现城 市化地区全覆盖, 部分区县黑臭水体情况因缺乏基 础数据而无法评价, 因此此类地区可直接根据 PM2.5 超标情况确定城市化地区专项评价结果, 即 将 PM2.5 超标情况为: 轻度和中度的划分为轻警, 重度的划分为中警,严重的划分为重警。

\section{3 结果分析}

\section{1 单项评价结果}

(1) 黑臭水体评价结果

2015 年, 试评价地区中有 31 个城区实施了黑 臭水体监测,包括北京市的朝阳、海淀、丰台、房山、 大兴、通州, 天津市的河东、南开、3个环城区以及武 清和滨海新区,河北省的石家庄、唐山、秦皇岛、廊 坊、保定、沧州、衡水、邢台、邯郸等市的市辖区。评 价结果显示, 水体黑臭情况严重的有 5 个区,情况一 般的有 14 个区,情况较轻的有 12 个区(表 5)。其中, 5 个严重区分别为北京市朝阳、丰台、大兴,天津市 武清以及河北衡水的桃城,主要分布在北运河水系 及㵚阳河水系的分布区域,5个区中尤以桃城黑臭水

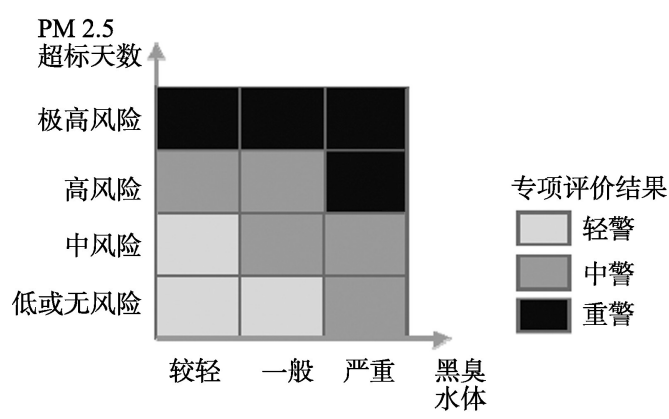

图 1 城市化地区专项评价结果分级图

Fig.1 Evaluation matrix of urbanized areas 
体情况最为严重,黑臭水体分布密度高达 $942 \mathrm{~m} / \mathrm{km}^{2}$, 且近半数为重度黑臭; 北京市的 3 个区及天津武清 的情况也相当严峻, 4 个区重度黑臭水体比重均超 过 $50 \%$, 其中丰台区重度黑臭水体比重更是达到 100\%, 区内黑臭水体治理已刻不容缓。情况一般 的 14 个区主要分布在北京郊区的昌平、房山、通州, 河北保定的竞秀、莲池,石家庄的桥东、桥西、新华, 邯郸的邯山及丛台区等, 虽然这些区的水体黑臭 情况比严重区要好一些,但部分重点开发区域如北 京通州、保定竞秀等黑臭水体分布密度均已超过 $500 \mathrm{~m} / \mathrm{km}^{2}$, 接近临界水平, 问题也不容忽视。

(2) PM2.5 超标天数评价结果

试评价地区 PM2.5 超标天数评价结果显示, 极 高风险的区县有 42 个, 主要沿 G1 高速一102 国道、 $\mathrm{G} 2$ 高速一105 国道、以及 $\mathrm{G} 4$ 高速一107国道一线分 布, 包括北京房山区, 廊坊的永清县、霸州市, 东部 唐山古冶区、开平区以及南部保定、石家庄、邯郸的 多个区县。其中, 保定市南部、石家庄北部、以及邯 郸北部的多个区县全年超标天数均超过 250 天, 且 年均 PM2.5 值也都在 135 以上; 保定的清苑区、徐水 区、甘部的峰峰矿区 PM2.5 年均值更是高达 150 , 是 整个地区中空气质量最为严峻的区域; 唐山市市区 及丰润、丰南等区县全年超标天数也都在 220 天左 右, PM2.5 平均值超过 110 。此外, 北京房山区虽然 PM2.5 平均值未超过 100 , 但超标天数达 236 天, 全 年有近 $2 / 3$ 都是中度及以上雾䨪天气。高风险的区 县有 51 个, 主要集中在京津一线、渤海沿岸以及石 家庄西部和衡水南部等地。其中石家庄的市区、井 陉矿区以及衡水南部的冀州市、患强县等重点开发 区域, 超标天数在 230 天左右, PM2.5 平均值达到 120 以上, 是高风险中较为严重的区域; 北京市中南 部地区、渤海沿岸如曹妃甸区、昌黎县等大气污染 程度则相对缓和, PM2.5 平均值普遍在 100 以下, 但 全年超标天数也在160 190天之间。中、低风险的 区县有 11 个, 其中, 中风险地区主要分布在秦皇岛 市的海港、山海关、北戴河区, 承德的鹰手营子矿 区, 以及天津的滨海新区; 低风险地区主要分布在 张家口市和承德市的市辖区。

进一步分析优化开发与重点开发 2 类区域 PM2.5 的超标情况, 发现优化开发区域PM2.5 超标 情况十分严峻, 重点开发区域也不容乐观。优化开 发区域的 54 个区县中, 除 3 个区县为中风险外, 其 余 51 个区县均为极高或高风险, 这些区县大多分布
表 5 京津冀城市化地区黑臭水体评价结果 Tab.5 The number of counties with different pollution levels of urban black-odor water bodies in the optimized and priority development zones in the Beijing-TianjinHebei region

\begin{tabular}{lrccc}
\hline 功能区 & 较轻 & 一般 & 严重 & 县域数合计 \\
\hline 优化开发区域 & 8 & 3 & 3 & 14 \\
重点开发区域 & 4 & 11 & 2 & 17 \\
合计 & 12 & 14 & 5 & 31 \\
\hline
\end{tabular}

在保定以南、石家庄以北区域,其中情况最为严重 的是清苑区、徐水区、峰峰矿区等; 重点开发区域的 50 个区县中, 极高或高风险区县共计 42 个,其中半 数以上区县为极高, 最为严重区域主要集中在保 定、廊坊和唐山三市。全部 104 个区县中,仅承德与 张家口市的 6 个区 PM 2.5 风险较低, 是京津冀城市 化地区中仅有的评价结果为低风险的区县(表 6)。

\section{2 集成评价结果}

集成结果显示(图 2), 京津冀城市化地区 104 个 区县中, 重警区县共 47 个, 主要分布在北京南部、唐 山西部、保定南部、石家庄北部以及邯䣋中部, 与 G1 高速一 102 国道一线、 $\mathrm{G} 2$ 高速一 105 国道一线、 以及 $\mathrm{G} 4$ 高速一 107 国道一线等分布具有一致性, 并 与河北省钢铁工业聚集格局大致相符。其中,优化 开发区域 19 个,主要集中在唐山、沧州、廊坊等地; 重点开发区域28个, 主要集中在石家庄、邯郸、保定 以及北京的房山、大兴等地。中警区县共 46 个, 主 要分布在北京北部、渤海沿岸以及衡水南部等地。 其中, 优化开发区域有 32 个, 主要集中在北京中心 城区、天津、唐山、沧州、秦皇岛等地; 重点开发区域 有 14 个,主要集中在石家庄、廊坊、衡水以及北京城 郊的通州、顺义、昌平等地。轻警区县共 11 个,在优 化开发与重点开发区域分别为 3 个和 8 个,主要分 布在河北张承地区和东部沿海区县,这些地区工业 相对较少, 且地理位置有利于污染物迅速扩散。

表 6 京津冀城市化地区 PM2.5 超标天数评价结果

Tab.6 The number of counties with different PM2.5 pollution degrees in the optimized and priority development zones in the Beijing-Tianjin-Hebei region

\begin{tabular}{|c|c|c|c|c|c|}
\hline \multirow{2}{*}{ 功能区 } & \multicolumn{4}{|c|}{ 县域数 } & \multirow{2}{*}{ 合计 } \\
\hline & 低或无 & 中 & 高 & 极高 & \\
\hline 优化开发区域 & - & 3 & 35 & 16 & 54 \\
\hline 重点开发区域 & 6 & 2 & 16 & 26 & 50 \\
\hline 合计 & 6 & 5 & 51 & 42 & 104 \\
\hline
\end{tabular}




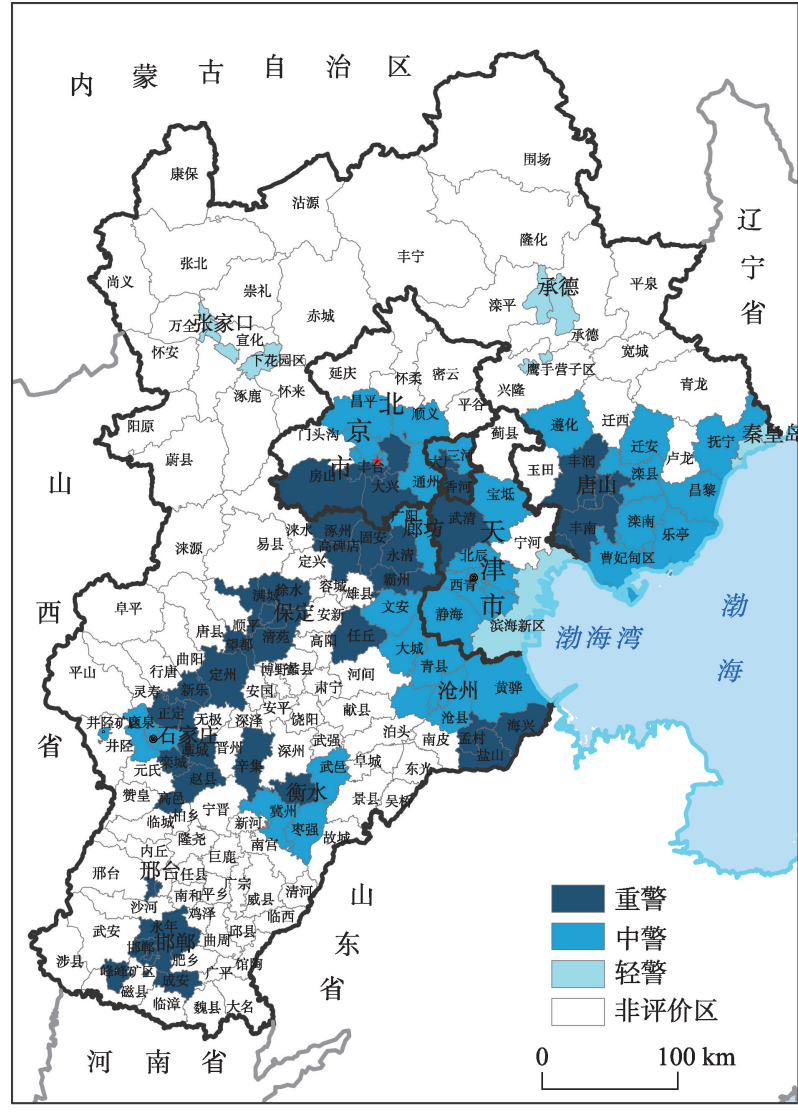

图2 京津冀城市化地区专项评价结果分布图

Fig.2 Specific evaluation results of urbanized areas in the Beijing-Tianjin-Hebei region

\section{4 结论与讨论}

本文基于城市化地区区域主体功能与自然资 源环境交互作用出发, 从主要的城市人居环境劣化 因子人手, 采用城市水气环境黑灰指数作为城市化 地区专项评价的主要指标, 探讨了单项指标评价、 评价阈值划分以及指标集成方法, 并对京津冀城市 化地区进行了试评价分析。试评价结果显示, 京津 冀城市化地区的 104 个区县中, 47 个区县为重警, 46 个中警, 仅 11 个为轻警。其中, 重警区县主要集 中在京广高铁沿线, 与地区主要交通路线分布以及 地区钢铁工业聚集格局一致; 中警区主要分布在京 津冀东部地区, 且大多集中在重警区县的外围区 域; 轻警区县则主要分布在北部的张承地区以及东 部沿海区县, 这些地区工业相对较少, 且地理位置 有利于污染物迅速扩散。评价结果除深刻地刻画 了京津冀城市化地区人居环境劣化程度的空间格 局外,还为揭示现阶段该地区资源环境超载成因提 供了依据。
城市化地区专项评价作为资源环境承载能力 预警评价体系的一部分, 是对区域基础评价的补充 和完善,显示了城市化地区人类活动开发功能及利 用效率对资源环境承载能力的影响。但城市作为 自然一社会一经济的复合系统, 具有结构复杂、功 能多样、动态开放等特性, 资源环境承载能力的影 响因子也相应地具有综合性与复杂性的特点, 因 此, 在进行全国范围的普适性专项评价时, 应全面 梳理不同区域的城市化地区资源环境承载能力的 主要矛盾,提取其中普遍存在的关键问题。本文依 据该原则, 从人居环境劣化问题人手, 以黑臭水体 和 PM2.5 为主导因子设计城市水气环境黑灰指数, 试评价结果显示该方法能够较准确地反映大多数 城市化地区的现实情况。但由于理论方法、数据等 方面的不足, 此方法但仍存在以下局限性:一是评 价指标内涵不够全面, 如从人群健康角度出发的 PM2.5 超标天数, 目前只考虑了超标天数、城市功 能、人口分布等特征, 而因浓度阈值变化对不同人 群的影响考虑不够, 在下一步工作中将通过抽样调 查等进行补充; 二是阈值划分理论基础较弱, 目前 还主要根据经验判断, 在理论上缺乏更为可靠的依 据, 需要结合实际工作进一步深化理论研究; 三是 评价指标适用范围的有限性, 由于数据获取原因, 目前的指标仅仅是对现阶段多数城市化地区主要 问题的反映，下一步工作中应兼顾部分地区的特殊 问题作进一步补充完善。由于城市处于持续动态 变化过程之中, 评价指标也应根据城市的动态发展 及其与资源环境要素矛盾的变化进行相应的调整 与优化。未来的研究,一方面需要依靠国家城市化 地区水气环境监测网络的完善, 以进一步满足实时 化、规范化、层次化的评价需求; 另一方面在资源环 境承载能力预警评价理论和方法体系不断完善的 基础上,进一步研究更加精确、更具普适性的城市 化地区专项评价方法。

\section{参考文献(References)}

柇杰. 2014. 人地系统可持续过程、格局的前沿探索 $[\mathrm{J}]$. 地理

学报, 69(8): 1060-1068. [Fan J. 2014. Frontier approach of the sustainable process and pattern of human-environment system[J]. Acta Geographica Sinica, 69(8): 1060-1068.]

㷊杰. 2016. 城市地理学进人城市规划领域的学术优势与协

同发展 $[\mathrm{M}] / /$ 栎杰, 等. 中国人文与经济地理学者的学术 探究和社会贡献. 北京: 商务印书馆: 42-87. [Fan J. 2016. The academic advantages of urban geography and its coordinated development with urban planning[M]//Fan J, et al. How Chinese human geographers influence decision mak- 
ers \& society. Beijing, China: The Commercial Press: 42-87.] 㚞杰, 王亚飞, 汤青, 等. 2015. 全国资源环境承载能力监测 预警(2014版)学术思路与总体技术流程 [J]. 地理科学, 35 (1): 1-10. [Fan J, Wang Y F, Tang Q, et al. 2015. Academic thought and technical progress of monitoring and earlywarning of the national resources and environment carrying capacity (V 2014)[J]. Scientia Geographica Sinica, 35(1): 1-10.] 方宇翘, 垗祖楠, 张国芗, 等. 1993. 城市河流中黑臭现象的 研究 [J]. 中国环境科学, 13(4): 256-262. [Fang Y Q, Qiu Z $\mathrm{N}$, Zhang G Y, et al. 1993. A study on the phenomenon of water blackening and smell in urban river[J]. China Environmental Science, 13(4): 256-262.]

傅崇辉, 王文军, 汤健, 等. 2014. PM2.5 健康风险的空间人口 分布研究: 以深圳为例 [J]. 中国软科学, (9): 78-91. [ Fu C H, Wang W J, Tang J, et al. 2014. Study on demographic spatial distribution of health risks caused by PM2.5: A case from Shenzhen[J]. China Soft Science, (9): 78-91.]

胡鞍钢. 2003. 城市化是今后中国经济发展的主要推动力 [J]. 中国人口科学, (6): 5-12. [Hu A G. 2003. Chengshihua shi jinhou Zhongguo jingji fazhan de zhuyao tuidongli[J]. Chinese Journal of Population Science, (6): 5-12.]

李宇军. 2014. 中国城市环境保护面临的挑战及其对策 $[\mathrm{J}]$. 云 南农业大学学报, 8(5): 104-109. [Li Y J. 2014. Urban environmental protection in China: Challenges and countermeasures [J]. Journal of Yunnan Agricultural University, 8(5): 104-109.] 刘晓丽, 方创琳. 2008. 城市群资源环境承载力研究进展及 展望[J]. 地理科学进展, 27(5): 35-42. [Liu X L, Fang C L. 2008. Progress and prospect of study on carrying capacity of resource and environment of city clusters[J]. Progress in Geography, 27(5): 35-42.]

陆大道, 㚞杰. 2012. 区域可持续发展研究的兴起与作用 $[\mathrm{J}]$. 中国科学院院刊, 27(3): 290-300, 319. [Lu D D, Fan J. 2012. The rise and effects of regional sustainable development studies in China[J]. Bulletin of Chinese Academy of Sciences, 27(3): 290-300, 319.]

吕斌, 孙莉, 谭文垦. 2008. 中原城市群城市承载力评价研究 [J]. 中国人口・资源与环境, 18(5): 53-58. [Lv B, Sun L, Tan W K. 2008. Urban carrying capacity evaluation of Zhongyuan City Agglomeration[J]. China Population, Resources and Environment, 18(5): 53-58.]

仇保兴. 2007. 第三次城市化浪潮中的中国范例: 中国快速 城市化的特点、问题与对策 [J]. 城市规划, 31(6): 9-15. [Qiu B X. 2007. Disanci chengshihua langchao zhong de Zhongguo fanli: Zhongguo kuaisu chengshihua de tedian, wenti yu duice[J]. City Planning Review, 31(6): 9-15.]

夏军, 张永勇, 王中根, 等. 2006. 城市化地区水资源承载力研 究 [J]. 水利学报, 37(12): 1482-1488. [Xia J, Zhang Y Y, Wang Z G, et al. 2006. Water carrying capacity of urbanized area[J]. Journal of Hydraulic Engineering, 37(12): 1482-1488.] 谢元博, 陈娟, 李巍. 2014. 雾䨝重污染期间北京居民对高浓 度 PM2.5 持续暴露的健康风险及其损害价值评估 $[\mathrm{J}]$. 环
境科学, 35(1): 1-8. [Xie Y B, Chen J, Li W. 2014. An assessment of PM2.5 related health risks and impaired values of Beijing residents in a consecutive high-level exposure during heavy haze days[J]. Environmental Science, 35(1): 1-8.]

徐琳瑜, 杨志峰, 李巍. 2005. 城市生态系统承载力理论与评 价方法[J]. 生态学报, 25(4): 771-777. [Xu L Y, Yang Z F, Li W. 2005. Theory and evaluation of urban ecosystem carrying capacity[J]. Acta Ecologica Sinica, 25(4): 771-777.]

许学强, 李邭. 2009. 改革开放 30 年珠江三角洲城镇化的回 顾与展望 $[\mathrm{J}$. 经济地理, 29(1): 13-18. [Xu X Q, Li X. 2009. Review and preview of the urbanization in Pearl River Delta in the past 30 years of reform and opening up[J]. Economic Geography, 29(1): 13-18.]

杨亮, 吕耀, 郑华玉. 2010. 城市土地承载力研究进展 $[\mathrm{J}]$. 地 理科学进展, 29(5): 593-600. [Yang L, Lv Y, Zheng H Y. 2010. Review on research of urban land carrying capacity [J]. Progress in Geography, 29(5): 593-600.]

于玉涁, 黄勇. 2010. 城市河流黑臭原因及机理的研究进展 [J]. 环境科技, 23(S2): 111-114. [Yu T B, Huang Y. 2010. Review of reason and mechanism of black and stink in urban rivers[J]. Environmental Science and Technology, 23 (S2): 111-114.]

周一星, 曹广忠. 1999. 改革开放 20 年来的中国城市化进程 [J]. 城市规划, 23(12): 8-13. [Zhou Y X, Cao G Z. 1999. The urbanization process in China in the past 20 years[J]. City Planning Review, 23(12): 8-13.]

Bai X M, Shi P J, Liu Y S. 2014. Realizing China's urban dream[J]. Nature, 509: 158-160.

Chan C K, Yao X H. 2008. Air pollution in mega cities in Chi$\mathrm{na}[\mathrm{J}]$. Atmospheric Environment, 42(1): 1-42.

Fan J, Wang Y F, Ouyang Z Y, et al. 2017. Risk forewarning of regional development sustainability based on a natural resources and environmental carrying index in China[J]. Earth's Future, doi: 10.1002/2016EF000490.

Fang C L, Liu X L. 2010. Comprehensive measurement for carrying capacity of resources and environment of city clusters in central China[J]. Chinese Geographical Science, 20(3): 281-288.

Huang S L, Chen C S. 1990. A system model to analyse environmental carrying capacity for managing urban growth of the Taipei Metropolitan Region[J]. Journal of Environmental Management, 31(1): 47-60.

Li X M. 2012. Study on urban environmental carrying capacity based on an inexact fuzzy multiobjective programming model[J]. Advanced Materials Research, 518-523: 1226-1232.

Liu H M. 2012. Comprehensive carrying capacity of the urban agglomeration in the Yangtze River Delta, China[J]. Habitat International, 36(4): 462-470.

Liu R Z, Borthwick A G L. 2011. Measurement and assessment of carrying capacity of the environment in Ningbo, China [J]. Journal of Environmental Management, 92(8): 2047-2053.

Meier R L. 1978. Urban carrying capacity and steady state considerations in planning for the Mekong valley region[J]. 
Urban Ecology, 3(1): 1-27.

Oh K, Jeong Y, Lee D, et al. 2005. Determining development density using the Urban Carrying Capacity Assessment System[J]. Landscape and Urban Planning, 73(1): 1-15.

Tehrani N A, Makhdoum M F. 2013. Implementing a spatial model of Urban Carrying Capacity Load Number (UCCLN) to monitor the environmental loads of urban ecosystems: Case study: Tehran metropolis[J]. Ecological Indicators, 32: 197-211.

Wei Y G, Huang C, Lam P T I, et al. 2015. Using urban-carrying capacity as a benchmark for sustainable urban development: An empirical study of Beijing[J]. Sustainability, 7 (3): $3244-3268$.
Widodo B, Lupyanto R, Sulistiono B, et al. 2015. Analysis of environmental carrying capacity for the development of sustainable settlement in Yogyakarta urban area[J]. Procedia Environmental Sciences, 28: 519-527.

World Health Organization. 2006. Air quality guidelines: Global update 2005: Particulate matter, ozone, nitrogen dioxide, and sulfur dioxide[M]. Copenhagen, Denmark: World Health Organization.

Zheng D F, Zhang Y, Zang Z, et al. 2015. Empirical research on carrying capacity of human settlement system in Dalian City, Liaoning Province, China[J]. Chinese Geographical Science, 25(2): 237-249.

\title{
Specific evaluation of resource and environmental carrying capacity of urbanized areas for early-warning: A case study of the Beijing-Tianjin-Hebei region
}

\author{
ZHOU Daojing ${ }^{1,2}$, WANG Chuansheng ${ }^{1,2}$ \\ (1. Key Laboratory of Regional Sustainable Development Modeling, CAS, Beijing 100101, China; \\ 2. Institute of Geographic Sciences and Natural Resources Research, CAS, Beijing 100101, China)
}

\begin{abstract}
Due to the serious resource and environmental problems in urbanized areas, it is necessary to carry out a specific evaluation on their typical problems in the early-warning of the resource and environmental carrying capacity. However, most of the existing studies are too complicated to operationalize for practical use, and they lack consideration of the differences among development stages. According to the resource and environmental problems highlighted in the urbanized areas in recent years, we adopted an urban black-gray index of water and air environment as the specific indicator to reflect the comfort degree of habitat environment in urbanized areas at the present stage. Meanwhile, the key thresholds of urban black-odor water bodies and PM2.5 pollution days were determined in line with the major functions of the optimized and prioritized zones. Based on the above method, this article presented an empirical analysis on the urbanized area in the Beijing-Tianjin-Hebei region. Trial evaluation shows that, in the Beijing-Tianjin-Hebei urbanized areas, 47 districts or counties were in the severe warning category, 46 were in the moderate warning category, and only 11 were in the mild warning category. The severe-warning districts or counties were mainly concentrated along the Beijing-Guangzhou highspeed railway, and the distribution pattern was consistent with the regional distribution of major traffic lines and steel manufacture aggregation. The mild-warning districts and counties were mainly distributed in the northern Zhangjiakou-Chengde area and the eastern coastal areas, where the industries were relatively few and the geographic location was conducive to the rapid spread of pollutants. In summary, as an indispensable supplement to basic evaluation of resource and environmental carrying capacity for early-warning, the specific evaluation for urbanized areas can reflect the main constraints of these areas more clearly, and determine the early-warning status of different functional zones in different development stages objectively. The evaluation provides a scientific basis for urban spatial planning, urban development strategy research, and industrial structure adjustment in urbanized areas
\end{abstract}

Key words: resource and environmental carrying capacity; early-warning evaluation; urbanized area; urban black-gray index of water and air environment; evaluation thresholds; Beijing-Tianjin-Hebei region 